\title{
Model of Sharia Hotel Characteristics with Transcendental Dialectics Method to Create Yogyakarta Tourism Competitiveness
}

\author{
Ahim Abdurahim ${ }^{1, *}$, Sigit Arie Wibowo ${ }^{2}$ \\ ${ }^{1}$ Accounting Department, Faculty of Economics and Business, Universitas Muhammadiyah Yogyakarta, Indonesia \\ ${ }^{2}$ Accounting Department, Faculty of Economics and Business, Universitas Muhammadiyah Yogyakarta, Indonesia \\ *Corresponding author. Email: ahim@umy.ac.id.
}

\begin{abstract}
The purpose of the study is to construct a model to measure the compliance of sharia hotels with sharia principles as a recommendation for authoritative institutions to issue sharia hotel operational permits. The research sites comprised Hotel Dafam Rohan Syariah Yogyakarta, Namira Syariah Hotel Yogyakarta, and Hotel Syariah Solo. Data were obtained by documentation, observation, interviews, and intuition. The informants consisted of the general manager, sharia supervisory board, chef manager, front desk, hotel guests, National Sharia Council-Indonesian Ulema Council members, and sharia experts. The research used a post-positive paradigm. The data were then analyzed employing the transcendental dialectics method, namely empirical data dialectically confirmed to Islamic law sources in the stages of data acquisition, content analysis, relevance analysis, correlation analysis, formulation of provisional conclusions, and triangulation to informants of National Sharia Council-Indonesian Ulema Council members and sharia experts. The parameters utilized were three levels of needs according to maqashid shariah, namely al-daruriyat, al-hajiyat, and al-tahsiniyat. The study resulted in a measurement model of compliance with sharia principles, divided into two groups: groups that met sharia requirements and did not meet sharia criteria. The group that met the sharia criteria was divided into three levels of service and facility quality, including good, very good, and excellent, based on three maqashid sharia parameters. This research implies that sharia hotels are not sufficiently classified based on conformity to sharia principles, but furthermore, sharia hotels must be classified based on the level of service quality and facilities provided.
\end{abstract}

Keywords: Performance, hotel, sharia, dialectic, transcendental, maqashid

\section{INTRODUCTION}

The existence of a formal sharia entity in Indonesia began in 1991 with the establishment of Bank Muamalat Indonesia, which operates based on sharia principles. The growth of Islamic financial institutions has accelerated with the enactment of Law Number 10 of 1998 concerning banking, which explicitly recognizes the existence of Islamic banking. The legality of sharia banking is getting stronger with the ratification of Law Number 21 of 2008 concerning Islamic banking. The presence of this law shows the recognition of Islamic banking as an important part of economic development in Indonesia.

The development of the legality of sharia entities also occurs in non-bank financial institutions, namely sharia pension funds. Although the existence of pension fund institutions has formal legality in 1992 through Law Number 11 of 1992 concerning Pension Funds, the law has not explicitly stated the legality of sharia pension funds. After 14 years later, the Financial Services Authority (OJK) issued Financial Services Authority Regulation Number 33/POJK.05/2016 concerning implementing a Pension Program Based on Sharia Principles, which explicitly states the existence of a Pension Fund that runs its operations under sharia principles. Based on two recognitions of sharia entities in banking financial institutions and non-bank financial institutions (Pension Funds), it is clear that there are institutions that have the authority to provide legitimacy as entities that carry out operations based on sharia principles.

In contrast to sharia entities other than financial institutions, several non-financial sharia entities, such as sharia hotels, sharia hospitals, or sharia transportation, do not yet have an authorization institution that legitimizes them as sharia entities. Several entities have independently established sharia certification bodies, such as the Indonesian Islamic Health Effort Council (MUKISI), to certify hospitals that wish to obtain recognition as hospitals operating following sharia principles (MUKISI 2019).

One of MUKISI's activities is to conduct an assessment and accreditation of hospitals that wish to obtain recognition (certification) as sharia hospitals. In conducting the assessment and accreditation of sharia hospitals, MUKISI uses an assessment instrument that measures the level of hospital compliance with sharia principles. The assessment instrument is a portrait of the hospital characteristics under sharia principles. As of September 2021, MUKISI has 
succeeded in providing assistance and certification to 25 sharia hospitals in Indonesia, with 42 hospitals currently in the preparation process.

Learning from the development of sharia hospitals and the efforts that MUKISI has made to anticipate the vacancy of sharia hospital assessment institutions and instruments, it is possible to form a similar institution that has the authority to provide assessment and accreditation to sharia hotels. Janitra (2017) argued that the regulator's role is vital in determining the formal status of the recognition of sharia hotels in Indonesia. In addition, the process of forming an institution authorized to provide sharia hotel accreditation requires a sharia hotel assessment instrument that refers to hotel characteristics following sharia principles (Janitra, 2017). Samori and Rahman's (2013b) research indicated that hospitality practitioners must have adequate knowledge and preparation in managing sharia hotels. For this reason, this study seeks to explore to construct a model of Islamic hotel characteristics using the Kaffah (holistic) Islamic perspective. The results of this study are expected to be a recommendation for a sharia hotel characteristic model as a reference in the preparation of sharia hotel accreditation assessments by institutions that have the authority to accredit sharia hotels to obtain sharia certification.

Moreover, based on the 2019 Global Muslim Travel Index (GMTI), Indonesia became the second country out of 10 Organizations of Islamic Conferences, the most important being a Muslim tourist destination. From the same data source, information was obtained that Indonesia became the top 10 Muslim tourist destinations globally. This information denotes that the potential for sharia tourism in Indonesia has high prospects. Nevertheless, this prospect will be achieved if the tourist accommodation services for visitors in Indonesia provide satisfaction, both for domestic and foreign tourists. More specifically, the Special Region of Yogyakarta is included in the ten priority areas for tourism development to increase foreign exchange and regional economy (Pratiwi, 2016).

\section{LITERATURE REVIEW}

Islamic economic research is generally carried out on Islamic financial and non-financial institutions and issues on halal products (Samori and Rahman 2013a); very few studies have been conducted on non-financial Islamic institutions, such as Islamic hotels (Salleh et al. 2014). The absence of an institution that has the authority to provide legitimacy for sharia hotels provides an opportunity to conduct in-depth studies to produce a strong foundation to support the existence and operational basis for institutions that have the authority to provide legitimacy for sharia hotels. Thus, academic studies will produce important recommendations to realize a sharia hotel recognized by the constitution. It is consistent with the research of Razalli et al. (2012) that to develop a sharia hotel, it is necessary to evaluate compliance with sharia principles and authoritative institutions authorized to conduct guidance and supervision of sharia hotel operations. As a result of the absence of standard parameters and authoritative institutions that foster and supervise compliance with sharia principles, it can lead to differences in sharia hotel standards used by hotels that claim to be sharia hotels (Karim et al., 2017).

Further, this research is very necessary to be carried out to help the development of tourism, especially to support the development of sharia tourism through the importance of the existence of sharia hotels (Samori and Rahman, 2013a). The development of sharia tourism has a strategic position for the people of Indonesia, which has a large Muslim population and has the potential to receive visits from foreign Muslim tourists. To support this, it is necessary to have an institution capable of assessing and accrediting sharia hotels with adequate academic studies.

Several researchers have carried out research related to sharia hotels, such as Samori and Rahman (2013b), who stated that hotel practitioners must have good knowledge and preparation in managing sharia hotels. It is because sharia hotel management has different characteristics from hotels in general. Against the background of differences in perceptions between academics and practitioners regarding sharia hotel operations, Razalli et al. (2012) researched consumer awareness of sharia hotel compliance. The results showed that consumers had a good awareness of sharia hotel compliance, but consumers did not have an adequate understanding of the characteristics of sharia hotels. It signifies that Islamic hotel parameters are crucial to be socialized to consumers.

Considering the growth of Muslim tourists in Malaysia, Razalli et al. (2012) conducted a study to assess the opportunities and challenges of the Islamic hotel business in Malaysia. The results revealed the high potential of Muslim tourists who needed sharia hotels in Malaysia. It raises challenges regarding the process of establishing a sharia hotel in Malaysia. The research showed the same thing in Indonesia, namely that the growth of sharia tourism encourages legal certainty regarding the process of establishing a sharia hotel with formal legality. The same research was also conducted by Samori and Rahman (2013b). However, these two studies have not provided answers to the problems in Indonesia, which are related to the absence of official institutions and parameters to measure sharia hotel compliance.

The research results by Razalli et al. (2012), followed up by Razalli et al. (2015), have studied in depth the concept of a sharia hotel and how to implement it. Unfortunately, the study has not produced conclusions that answer the implementation of sharia hotels comprehensively. The issue of uncertainty about the attributes or parameters of sharia hotels was then presented by Karim et al. (2017), who asserted that sharia hotel managers were still confused about the characteristics of sharia hotels. With qualitative methods and in-depth interviews with two sharia hotels, it is shown that there were differences in the attributes used by the two sharia hotels. 
Moreover, the research of Salleh et al. (2014) stated that the implementation of sharia hotel management was hampered by three things: the absence of legal certainty from the government, difficulties in meeting halal standards, and the absence of standards to measure sharia hotels. Their research supports the purpose of this study, namely, to encourage legal certainty of the existence of sharia hotels and produce a model of sharia hotel characteristics that can be used to assess compliance with sharia principles.

Based on experience in recognition of sharia banking that does not categorize the level of compliance with sharia principles, it turns out that this has a bad impact on the image of sharia banking as a whole. If there are Islamic banks whose operational activities are not following sharia principles, the public tends to evaluate Islamic banking as a whole. To avoid the same thing in sharia hotels, it is necessary to categorize the level of compliance of sharia hotels with sharia principles. One of the categorizations that can be used is the categorization of the level of fulfillment of needs to realize the benefits formulated in maqashid shariah, consisting of aldaruriyat, al-hajiyat, and al-tahsiniyat (Bakri 1996; Audah 2013). In the context of sharia hotel research, what is meant by al-daruriyat needs are the environment, facilities, and infrastructure that sharia hotels must meet. If these needs are not met, the main objectives of sharia hotels will not be achieved. The needs of al-hajiyat are the environment, facilities, and infrastructure, which, if fulfilled by sharia hotels, the main purpose of sharia hotels will be achieved and supported by the fulfillment of al-hajiyaat (secondary) needs. Furthermore, the need for al-tahsiniyat is that if sharia hotels fulfill the environment, facilities, and infrastructure, the objectives of sharia hotels that are al-tahsiniyat (tertiary) will be achieved more perfectly.

\section{RESEARCH METHOD}

Under the research objective, which is to construct a measurement model of sharia hotel compliance with sharia principles, this study used research sites at Hotel Dafam Rohan Syariah Yogyakarta, Namira Syariah Hotel Yogyakarta, and Hotel Syariah Solo, which used branding as a sharia hotel. The selection of a site at a hotel that uses sharia hotel branding as an object or research site is considered appropriate because it has consequences for carrying out its operations under sharia principles.

Data were obtained by in-depth interviews, archive documentation, and observations of site operational activities (Denzin and Lincoln, 2009). The selection of informants was by combining the purposeful method and the snowballing method (Abdurahim et al., 2016). The purposeful method was used to select informants suspected of having relevant information related to the characteristics of sharia hotels. Meanwhile, the snowballing method was employed to select the follow-up informants based on the instructions from the informants obtained with the purposeful method that the follow-up informants had relevant information related to the research. The informants used in this study were the general manager, sharia supervisory board, chef manager, front office, and hotel guests. The data obtained were tested for validity with informants from the National Sharia CouncilIndonesian Ulema Council members and sharia experts.

The research applied a post-positive approach, where researchers obtained data by being directly involved in activities with informants to explore information in-depth and naturally. The research paradigm employed a religious paradigm with the perspective of Aminullah. This approach involves the senses, mind, and heart in the acquisition and analysis of data based on the belief that the source of knowledge comes from Allah SWT. Therefore, the researchers used the senses to capture empirical data and normative sources of Islamic teachings, confirmed and analyzed empirical data and normative data with reason, and intuitively used the heart in every research stage, up to drawing conclusions. Thus, data were obtained by documentation, interview, observation, and intuitive techniques. The data analysis then utilized transcendental dialectic, i.e., empirical data were dialectically confirmed to Islamic law sources in each data processing stage. The transcendental dialectical method is based on revelation truth theory (Ahim Abdurahim, 2016). The revelation truth theory states that the universe and its laws are the creation of Allah SWT, and Al Qur'an ul Karim is the revelation of Allah SWT, which was revealed to the Prophet Muhammad SAW, explaining laws that exist in the universe. Therefore, if the universe and/or the Qur'an are studied in-depth using the senses, reason, and heart, it will obtain the conformity of the laws described between the two. Even so, because humans have the potential for error, the study of the senses, reason, and heart of the universe and the Qur'an must be contemplated to gain knowledge of Allah SWT, dhikr to get closer to Allah SWT, praying for useful knowledge, contemplating for exploring knowledge, and a heart that surrenders and believes that Allah SWT will provide useful scientific instructions.

Furthermore, after the data were obtained, the data were analyzed as follows: a) Relevance analysis was done to sort between data relevant to the research question and data not relevant to the research question. The irrelevant data were reduced, while the relevant data were further processed. b) The relevant data were then analyzed for content (coagulation) using maqashid shariah parameters. Using the maqashid sharia parameters, data groups with similar meanings were obtained based on al-daruriyat, al-hajiyat, and al-tahsiniyat elements. c) Correlation analysis was performed to analyze data by systematizing data with similar meanings to construct answers to research questions. If there are unanswered research questions, the researchers must collect additional relevant, content, and correlated data to answer the research questions. d) The next step was to formulate tentative conclusions based on data groups with similar meanings and strong arguments to answer the research questions. e) Then, to obtain the data validity, the researchers confirmed the formulation of temporary conclusions to the National Sharia Council-Indonesian Ulema Council members in the field of sharia industry, business, and economics and 
experts in the field of sharia science (triangulation. $\mathrm{f}$ ) The last stage was to formulate the research results. Simultaneously, each stage of acquisition, data analysis, formulation of provisional conclusions, triangulation, and formulation of research results was carried out by using intuition techniques, namely doing the intention of seeking useful knowledge because of Allah SWT, dhikr closer to Allah SWT, praying to Allah SWT to obtain useful knowledge, and surrendering and having a good attitude towards Allah SWT will provide guidance and useful knowledge (tawakkal) (Ahim Abdurahim, 2016). Here, the intuition stage is inseparable in the transcendental dialectical method, which believes that the truth of science comes from Allah SWT.

To produce a measurement model of hotel compliance with sharia principles, three types of needs according to maqashid shariah parameters were utilized, namely aldaruriyat, al-hajiyat, and al-tahsiniyat (Bakri, 1996; Audah, 2013). The study resulted in a measurement model of compliance with sharia principles, which was measured into two groups: the group that met the sharia criteria and did not meet the sharia criteria. Groups that met the criteria for complying with sharia principles were further divided into three levels of service quality and facilities, including the good, very good, and excellent, based on maqashid parameters.

\section{RESULTS AND DISCUSSION}

In this study, sharia experts agreed that absolute requirements distinguish sharia hotels from conventional hotels, although the elements of what requirements are absolutely fulfilled need to be explored further. Sharia experts also argued that intention is the main and important factor in every activity. It is in accordance with the hadith narrated by Bukhari and Muslim, which states that every action depends on the intention; if the act is not intended because of Allah SWT and according to the sunnah of the Messenger of Allah, the act is not accepted by Allah SWT (Al'Ied, 2001; Sayik, 2017). In practice, the statement of intention to worship because of Allah SWT is manifested in the form of an explicit statement that the hotel is established as a sharia hotel, namely a hotel whose operational activities are under sharia principles. The statement is formally stated in the operating permit of the sharia hotel, as well as a statement in the articles of association and by-laws of the hotel. The Sharia Supervisory Board and the hotel's general manager stated that in the publication of hotel products and activities, management must state the identity as a sharia hotel and use symbols or trademarks of sharia hotel. From information from experts, general managers, hotel supervisory boards, and the hadith of the Prophet Muhammad, it can be concluded that there are basic elements that must be met by hotels or are classified as al-daruriyat elements, namely formal statements from hotel management both in the form of statements through the articles of association and by-laws, as well as media publications to the public. The formal statement of status as a sharia hotel is part of the transparency of hotel management to the public. Sharia hotels also have an obligation to convey information that is the right to be known by the public (Alserhan et al., 2018).

In addition to the element of intention, experts also stated that halal and haram issues are mandatory requirements for sharia hotels, including halal and haram matters for food, drinks, and other types of non-mahram relationships. Sharia hotels are prohibited from providing, selling, and allowing the consumption of food and beverages that are forbidden in Islamic law. Information obtained from the general manager, the hotel's sharia supervisory board, chef manager, the National Sharia Council-Indonesian Ulema Council members, and Sharia experts stated that the hotel has a halal certificate for serving the hotel ingredients and food. In addition, the general manager, the supervisory board, and the hotel front desk explained that the front desk always indicated that male and female guests who were not mahrams were not allowed to stay in the same room without being accompanied by their mahram. The researchers obtained documents in the form of notes given to each guest and announcements in the rooms, which prohibited non-mahram women from being in the same room without their mahram.

Empirical data is, of course, following the Qur'an and alhadith, which put the importance of the intention to worship Allah, the prohibition against liquor, forbidden food, and every act that approaches adultery. The informant's opinion aligns with the National Sharia Council-Indonesian Ulema Council Fatwa Number 108 regarding sharia tourism (DSNMUI 2016). The importance of eliminating elements forbidden in the Qur'an and as-hadith has been studied by Saad and Ali (2014), who conducted hotel research in Egypt. The research of Saad and Ali (2014) stated that haram food and drinks and acts closer to adultery are absolutely prohibited in sharia hotels.

Thus, empirical data from management, guests, the National Sharia Council-Indonesian Ulema Council members, and sharia experts agreed that the mandatory requirements must be met to obtain sharia hotel accreditation. If these requirements are not met, the hotel is not eligible as a sharia hotel. The requirements must be met, including a statement that it operates as a sharia hotel, does not provide haram food and drinks, and avoids adultery. In addition, the informants also agreed that sharia hotels are required to provide worship facilities, although the minimum standards that must be provided varied from one informant to another.

Moreover, the family guests from the Muslim community whom the researchers interviewed stated that they were very happy with the Islamic atmosphere and facilities and infrastructure at the sharia hotel. Furthermore, when asked about the different levels of Islamic atmosphere and infrastructure available in other hotels visited, the guests considered it necessary to have a classification or level of compliance with sharia principles among sharia hotels according to the Islamic atmosphere and facilities and infrastructure. The consideration is that the community, especially Muslims, has the right to choose to obtain a quality 
level of compliance with sharia principles for each hotel according to the choice of the hotel they want. In addition, hotel guests also stated that the existence of this classification would motivate sharia hotels to compete in increasing compliance with sharia principles. It is in accordance with the research of Razalli et al. (2015) that sharia hotel consumers in Malaysia wanted good service consisting of five main services with 64 attributes.

The general manager said that compliance with sharia principles provides comfort to the Muslim community and Muslim families while staying at the hotel. The reason is that the Islamic atmosphere and infrastructure facilities provide easy guidance to employees for Muslim community leaders and provide convenience in maintaining Islamic guidance to family members for family guests. It strongly supports guest loyalty to visit and hold activities at Hotel Dafam Rohan Syariah Yogyakarta, Namira Syariah Hotel Yogyakarta, and Hotel Syariah Solo. The information from the general manager is in accordance with the research of Purnamasari and Darma (2015), which stated that the quality of compliance with sharia principles impacted increasing consumer loyalty.

Further, the researchers observed the Islamic atmosphere and the worship facilities at the sharia hotel. Some hotels provided prayer rooms but did not routinely facilitate the five daily prayers in the congregation and did not facilitate regular mosque imams at every obligatory prayer time. A hotel also provided a prayer room and facilitated guests to pray five times a day together. Some other hotels provided mosques that facilitated guests to pray five times in congregation, Friday prayers, and routine Islamic studies. The results of these observations are consistent with the explanations of hotel guests from their experiences as guests at several sharia hotels. It showed that there were different levels between one hotel and another. In addition, the guests of the Muslim community and Muslim families stated that they were very proud if there was a sharia hotel with facilities and infrastructure that are not inferior to conventional hotels with four or five stars. The hotel guests further emphasized that sharia hotels with excellent facilities can be a medium of propaganda for the community that Islamic values do not conflict with the best quality of service. Therefore, the ideal sharia hotel facilitates the spiritual aspects of a sharia hotel well and provides facilities with convenience and comfort for guests under sharia principles.

Information from informants also uncovered different levels of compliance with sharia principles among sharia hotels that affected people's choices in choosing the hotel they wanted. The informant also stated that service compliance with sharia principles influenced guests' satisfaction and loyalty to sharia hotels. It can be concluded that there are levels of sharia hotel services that are al-hajiyat, namely facilities that provide better comfort to guests and sharia hotel services that are al-tahsiniyat, namely facilities that provide physical and spiritual perfection to hotel guests.

\section{REFERENCES}

[1] Abdurahim, A., I. Triyuwono, A. D. Mulawarman, and M. Achsin. 2016. Aminullah: Revealing the Spiritual Values in Sharia Transaction. International Journal of Management and Administrative Sciences (IJMAS) 4 (1):65-73.

[2] Ahim Abdurahim, I. T., Aji Dedi Mulawarman, Mohammad Achsin. 2016. Akuntansi Syariah Holistis: Sebuah Refleksi dari Metode Dialektika Transendental dalam Perspektif "Aminullah", Program Doktor Ilmu Akuntansi, Universitas Brawijaya, Malang.

[3] Al'Ied, I. D. 2001. Syarah Hadits Arbain. Translated by M. Thalib. Yogyakarta: Media Hidayah.

[4] Alserhan, B. A., B. P. Wood, R. Rutter, D. Halkias, H. Terzi, and O. Al Serhan. 2018. The transparency of Islamic hotels: "Nice Islam" and the "self-orientalizing" of Muslims? International Journal of Tourism Research 20 (4):475-487.

[5] Audah, J. 2013. Al-Maqasid Untuk Pemula. Translated by A. Abdulmonim. Yogyakarta: SUKA-Press UIN Sunan Kalijaga.

[6] Bakri, A. J. 1996. Konsep Maqashid Al-Syariah Menurut AlSyatibi. Jakarta: RajaGrafindo.

[7] Denzin, N. K., and Y. S. Lincoln. 2009. Handbook of Qualitatieve Research. Yogyakarta: Pustaka Pelajar.

[8] DSN-MUI. 2016. Fatwa Dewan Syariah nasional - Majelis Ulama Indonesia nomor 108/DSN-MUl/X/2016 Tentang pedoman Penyelenggaraan Pariwisata Syariah Berasarkan Prinsip Syariah. Jakarta: DSN-MUI.

[9] Janitra, M. R. 2017. Hotel Syariah: Konsep dan Penerapan. edited by H. S. K. d. Penerapan. Depok: RajaGrafindo Persada.

[10] Karim, M. H. A., R. Ahmad, and N. A. Zainol. 2017. Differences in hotel attributes: Islamic hotel and shariacompliant hotel in Malaysia. Journal of Global Business and Social Entrepreneurship 1 (2).

[11] MUKISI. 2019. Profile MUKISI 2019 [cited 15 Agustus 2019]. Available from https://mukisi.com/profil/.

[12] Pratiwi, A. E. 2016. Analisis pasar wisata syariah di kota yogyakarta. Media Wisata 14 (1).

[13] Purnamasari, I., and E. S. Darma. 2015. Pengaruh Implementasi Syariah Governance Terhadap Loyalitas Nasabah. Journal of Accounting and Investment 16 (1):12-24.

[14] Razalli, M. R., S. Abdullah, and M. G. Hassan. 2012. Developing a model for Islamic hotels: Evaluating opportunities and challenges.

[15] Razalli, M. R., R. M. Ismail, and N. A. Yaacob. 2015. SIHAT: an assessment tool for Shariah-compliant hotel operations. International Journal of Islamic Marketing and Branding 1 (1):55-68.

[16] Saad, H. E., and B. N. Ali. 2014. Sharia-compliant hotels in Egypt: Concept and challenges. Advances in Hospitality and Tourism Research (AHTR) 2 (1):1-15.

[17] Salleh, N. Z. M., A. B. A. Hamid, N. H. Hashim, and S. Z. Omain 2014. The practice of Shariah-compliant hotel in Malaysia. International Journal of Trade, Economics and Finance 5 (1):26.

[18] Samori, Z., and F. A. Rahman. 2013a. Establishing shariahcompliant hotels in Malaysia: Identifying opportunities, exploring challenges. West East Journal of Social Sciences 2 (2):95108.

[19] 2013b. Towards the formation of Shariah-compliant hotel in Malaysia: an exploratory study on its opportunities and challenges. Paper read at WEI International Academic Conference Proceedings, Istanbul, Turkey.

[20] Sayik, S. S. A. 2017. RingkasanSyarah Hadits Arba'in An Nawawi. 